\title{
OPEN De novo super-early progeny in interspecific crosses Pisum sativum L. $\times$ P. fulvum Sibth. et Sm
}

\author{
Hatice Sari ${ }^{\bowtie}$, Duygu Sari, Tuba Eker \& Cengiz Toker
}

Earliness in crop plants has a crucial role in avoiding the stress of drought and heat, which are the most important challenging stressors in crop production and are predicted to increase in the near future due to global warming. Furthermore, it provides a guarantee of vegetable production in the short growing season of agricultural lands in the northern hemisphere and at high altitudes. The growing human population needs super early plant cultivars for these agricultural lands to meet future global demands. This study examined de novo super-early progeny, referred to as much earlier than that of the earlier parent, which flowered in 13-17 days and pod setting in 18-29 days after germination, discovered in $F_{2}$ and studied up to $F_{5}$ derived from interspecific crosses between garden pea ( $P$. sativum $L$.) and the most distant relative of pea ( $P$. fulvum Sibth. et Sm.). De novo super-early progeny were found to be earlier by about one month than $P$. sativum and two months than $P$. fulvum under short day conditions in the $F_{5}$ population. In respect of days to flowering and pod setting, de novo super-early progeny had a relatively high level of narrow sense heritability $\left(h^{2}=82 \%\right.$ and $80 \%$, respectively), indicating that the selections for earliness in segregating populations was effective for improvement of extreme early maturing varieties. De novo super-early progeny could be grown under heat stress conditions due to the escape ability. Vegetable types were not only high yielding but also free of any known undesirable traits from the wild species, such as pod dehiscence and non-uniform maturity. It could be considered complementary to "speed breeding", possibly obtaining more than six generations per year in a suitable climate chamber. Not only de novo super-early progeny but also transgressive segregation for agro-morphological traits can be created via interspecific crosses between $P$. sativum and $P$. fulvum, a precious unopened treasure in the second gene pool. Useful progeny obtained from crossing wild species with cultivated species reveal the importance of wild species.

Pisum sativum L. is the second most important plant at the point of production among grain legumes with 21.8 million tons of vegetable pea and 14.2 million tons of dry pea in 2019 in the world ${ }^{1}$. Wide areas of usage of pea and high nutritional value make it important. Green pea is harvested before the seed is mature for the fresh or canned market ${ }^{2}$ and fresh pods are consumed as vegetables ${ }^{3,4}$. Pea is not only used as dry, frozen and in animal feed $^{5}$, but is also of great importance as a rotation $\operatorname{crop}^{6,7}$ since it improves soil microbial diversity, protects soil water, and enriches the soil organic matter content ${ }^{8}$. Pea, like other legumes, fixes atmospheric nitrogen from the air into the soil. Nodules in pea roots transform atmospheric nitrogen $\left(\mathrm{N}_{2}\right)$ to ammonia $\left(\mathrm{NH}_{3}\right)$ with the bacteria Rhizobium leguminosarum ${ }^{6,9}$. Pea is a high-quality source of vegetable nutrition because of its high levels of digestible protein, balanced amino acids ${ }^{2}, \mathrm{~B}$ vitamins and dietary fiber. According to the above-mentioned special characteristics, pea is one of the major crops required to meet the food needs of the growing human population with its high-quality nutritional content.

It is thought that the long generation time of most plant species will create a bottleneck in meeting future food demands and in the application of breeding research ${ }^{10}$. Such needs have increased the need for new technologies such as speed breeding (SB). In the speed breeding procedure, it is aimed for plants to produce more than one generation in one year by growing them under controlled conditions for $22 \mathrm{~h}$ light and $2 \mathrm{~h} \mathrm{dark}{ }^{10,11}$. It has been reported that 6 generations of wheat (Triticum aestivum and Triticum durum), barley (Hordeum vulgare), chickpea (Cicer arietinum) and pea (P. sativum) and 4 generations of canola (Brassica napus) have been obtained in one year using speed breeding ${ }^{10,11}$. Speed breeding allows the use of promising technology, but due to the high 


\begin{tabular}{|c|c|c|c|c|c|c|}
\hline Species & Parents & Flower color & Seed color & Seed shape & 100-seed weight $(\mathrm{g})$ & Resistance to a/biotic stresses \\
\hline P. sativum & ACP 20 & & & Wrinkled & 42.8 & Powdery mildew \\
\hline P. fulvum & AWP 600 & & & Smooth & 5.4 & Powdery mildew, seed beetle \\
\hline
\end{tabular}

Table 1. Some agro-morphological and salient traits of parents used in interspecific crosses $P$ sativum $\times P$. fulvum.

costs, this technology is not available everywhere. Therefore, it is necessary to develop genetically early varieties, which are cheaper and more easily accessible.

Earliness, early maturity and yield are the important traits in pea, which determine the pea variety selected by farmers. Flowering time plays a major role in the adaptation of pea to different environments, especially in regions where growth is limited. Wide variations have been reported for the flowering time of pea ${ }^{12-14}$. It has been reported to vary from 140 to 220 days during the growing season in pea-growing regions of Sweden ${ }^{15}$. Earliness is not only crucial to avoid end of season frost ${ }^{16}$ but is also a substantial trait to increase pea productivity by avoiding drought and heat ${ }^{17,18}$. More than 20 loci have been determined in pea related to flowering time and inflorescence improvement. Flowering time is controlled by five major loci in the Pisum L. The late flowering $(L f)$ locus $^{19}$ prevents flowering in long and short days ${ }^{20,21}$, but there are numerous allelic variants of $L f$ with both naturally arising and induced mutant alleles. It has been reported that in genotypes with the $L f$ gene, extreme earliness occurs when it is deleted or inactivated by nonsense mutations ${ }^{21,22}$. Recessive alleles at the high response $(\mathrm{Hr})$ locus encourage early flowering in short days and reduce the photoperiod response, while the sterile nodes $(S n)$ locus confers a response to the photoperiod ${ }^{19,23,24}$. Dominant alleles at the early $(E)$ locus ${ }^{24}$ induce early flowering in some genetic background $s^{14,25-27}$, but this effect may show a complicated interaction with other loci ${ }^{28,29}$. Allelic differences in $L f, H r, S n$ and $E$ loci interact, resulting in a very wide range of flowering times of plants in non-inductive conditions ${ }^{14,19,22,24,28}$. The Die Neutralis (Dne) locus reduces the photoperiod response like the $\mathrm{Hr}$ locus, and encourages early flowering in short days ${ }^{24,27,29,30}$. Previous studies have examined the genetics of flowering, QTL (Quantitative trait loci) studies related to flowering, and inheritance of days to flowering (earliness) in the genus Pisum L. ${ }^{12-14,19,21,22,24,27,29-33}$. However, the variations including earliness, inheritance of earliness and transgressive segregations, coined as the presence of progeny with values greater or less than the values of their parents in segregated generations ${ }^{34-36}$, and de novo super-early progeny (referred to as progeny with flowering or pod setting and maturity much earlier than the early parent in segregating generations) derived from interspecific crosses between $P$. sativum and P. fulvum have not been studied according to the available literature. Therefore, the purpose of this study was (1) to select de novo super-early progeny, (2) to reveal the narrow sense heritability of days to flowering, days to pod setting, and important agro-morphological traits in $\mathrm{F}_{2}$ and $\mathrm{F}_{3}$ populations, and (3) to determine the transgressive segregations to select superior lines for important agro-morphological traits in $\mathrm{F}_{2}$ and $\mathrm{F}_{5}$ populations.

\section{Results}

The seed coat color (testa) and surface of P. sativum (ACP 20) were seen as yellowish cream and wrinkled, while these traits were recorded as black and smooth in P. fulvum (AWP 600) (Table 1). After pollination, the seed coat color and surface were found to be black and smooth in reciprocal interspecific crosses between $P$. sativum $\times P$. fulvum and $P$. fulvum $\times$ P. sativum. Both $\mathrm{F}_{1}$ plants derived from reciprocal interspecific crosses had black seed coat and smooth seed coat. The flower color of $F_{1}$ plants was orange, while P. sativum and P. fulvum had white and orange flower colors, respectively. The flower color in the plants derived from the $\mathrm{F}_{2}$ population were separated as three distinct categories of orange, fuchsia and white colors (Fig. 1). Segregations for flower color were fit well to 12 (orange) :3 (fuchsia) :1 (white), dominant epistasis (Table 2).

Heterosis in $\mathbf{F}_{1}$ progeny. For days to flowering and days to pod setting traits, the $\mathrm{F}_{1}$ plants derived from interspecific crosses $P$. sativum $\times$ P. fulvum had negative average heterosis values of $-27 \%$ and $-22 \%$, respectively (Fig. 2). Plant height had a heterosis value of 95\%, while the first pod height had a heterosis of $195 \%$. Heterosis for the pods per plant, the seeds per pod, pod length and biological yield traits was found to be $49 \%$, $-9 \%,-30 \%$, and $27 \%$, respectively. For the seed yield per plant, considerable heterosis was detected at $42 \%$, while heterosis for the harvest index was $38 \%$ (Fig. 2).

Transgressive segregation for agro-morphological traits in $F_{2}$ and $F_{3}$ populations. In the $F_{2}$ population, 121 individual plants from four $\mathrm{F}_{1}$ plants derived from interspecific crosses $P$. sativum $\times$ P. fulvum were grown in the same glasshouse. Plant height for $P$. sativum and $P$. fulvum was $137 \mathrm{~cm}$ and $41.3 \mathrm{~cm}$, respectively (Table 3). Plant height for $\mathrm{F}_{2}$ and $\mathrm{F}_{3}$ populations was determined to be $16-244 \mathrm{~cm}$ and $7-252 \mathrm{~cm}$, respec- 


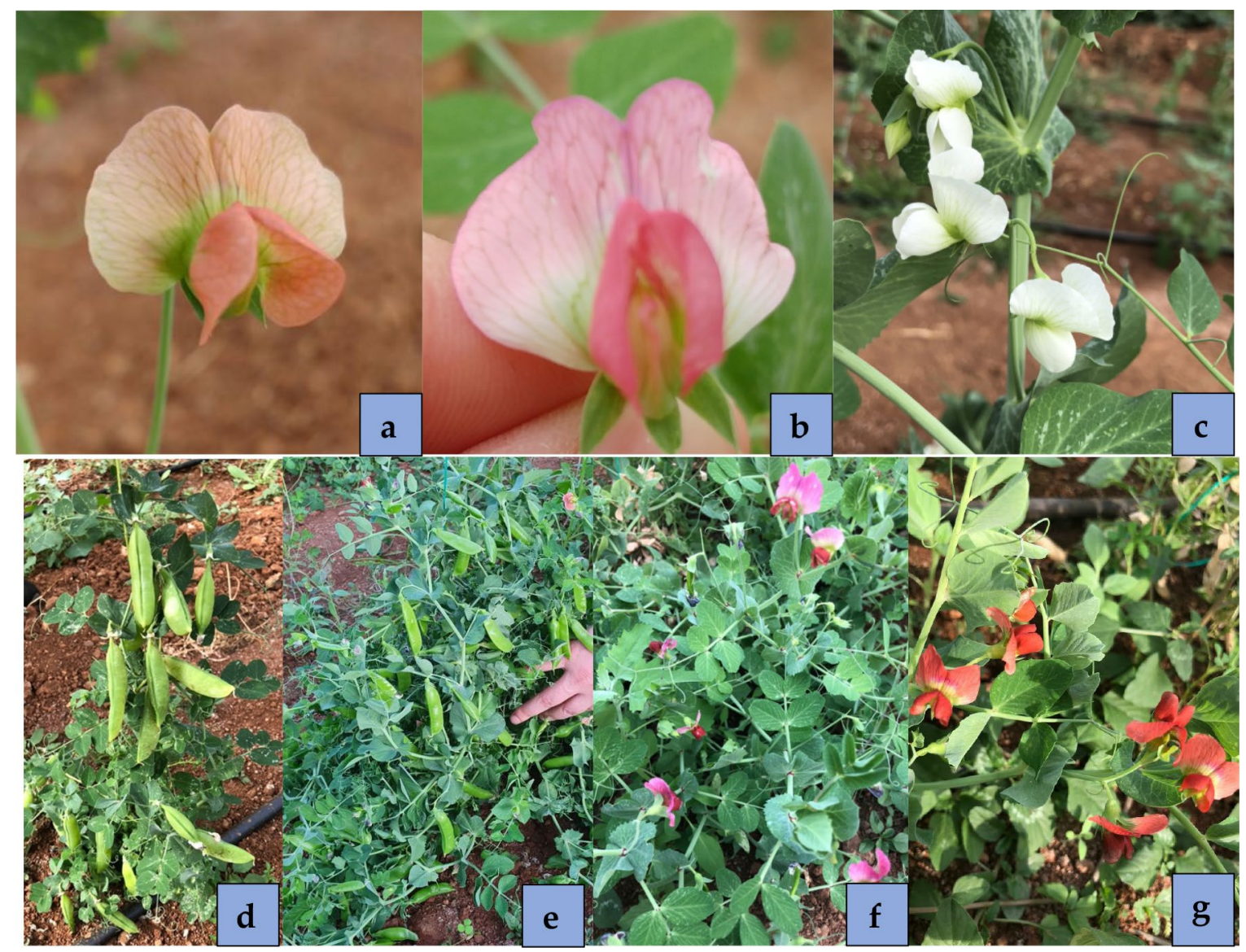

Figure 1. Orange (a), fuchsia (b) and white (c) flower colors in $F_{2}$ population derived from interspecific crosses P. sativum (ACP 20) $\times$ P. fulvum (AWP 600). Super early progeny for fresh seeds (d), Super early progeny for vegetables $(\mathbf{e})$, View of the lines $(\mathbf{f}, \mathbf{g})$.

\begin{tabular}{|c|c|c|c|c|c|c|c|}
\hline \multirow[b]{2}{*}{ Crosses } & \multirow[b]{2}{*}{ Flower color $\left(F_{1}\right)$} & \multirow[b]{2}{*}{ Flower colors $\left(F_{2}\right)$} & \multirow[b]{2}{*}{ Estimated ratio } & \multicolumn{2}{|c|}{ No of plants } & \multirow[b]{2}{*}{$x^{2}$} & \multirow[b]{2}{*}{$P$} \\
\hline & & & & Observed & Estimated & & \\
\hline \multirow{3}{*}{ ACP $20 \times$ AWP 600} & \multirow{3}{*}{ Orange } & Orange & 12 & 77 & 86.2 & \multirow{3}{*}{7.73} & \multirow{3}{*}{$0.25-0.1$} \\
\hline & & Fuchsia & 3 & 24 & 21.5 & & \\
\hline & & White & 1 & 14 & 7.2 & & \\
\hline
\end{tabular}

Table 2. Chi-square analysis for flower color in interspecific crosses P. sativum $\times$ P. fulvum.

tively. The number of pods per plant was 18 for P. sativum and 22.7 for P. fulvum, between 7 and 81 in $\mathrm{F}_{2}$, and 1 and 68 in $\mathrm{F}_{3}$ population. The number of seeds per pod in P. sativum and fulvum was 4.7 and 3, respectively, and 1-4.7 in $\mathrm{F}_{2}$ and 1-5 in $\mathrm{F}_{3}$ population. The biological yield was $86.5 \mathrm{~g}$ for P. sativum and 27. 2 for P. fulvum, the seed yield was $33.4 \mathrm{~g}$ for P. sativum and 3.9 for P. fulvum, and the harvest index was $38.3 \%$ for P. sativum and $14.4 \%$ for P. fulvum. Biological yield was $26-237 \mathrm{~g}$ for $\mathrm{F}_{2}$ population and 4-243 $\mathrm{g}$ for $\mathrm{F}_{3}$ population, seed yield was $10-83 \mathrm{~g}$ for $\mathrm{F}_{2}$ population and $4.2-79.8 \mathrm{~g}$ for $\mathrm{F}_{3}$ population (Table 3 ).

De novo super-early progeny. The number of days to flowering was recorded as 50.3 days for P. sativum and 123.7 days for $P$. fulvum, while the de novo super-early progeny flowered 17 days after germination in $\mathrm{F}_{2}$ population and after 13 days in $\mathrm{F}_{3}$ population. The number of days to pod setting was 57.7 days for $P$. sativum and 133.3 days for P. fulvum. The de novo super-early progeny formed pods in 29 days in $\mathrm{F}_{2}$ population and in 18 days in $\mathrm{F}_{3}$ population (Fig. 3 and Table 3).

Days to flowering in $\mathrm{F}_{2}$ and $\mathrm{F}_{3}$ populations was found to be appropriate bimodal distribution (Fig. 3a,b) as early (earlier than the domesticated pea) and late (later than the domesticated pea) plants. Distribution on days to flowering was found to be fit well to 9 (late progeny):7 (early progeny) segregation ratio in $\mathrm{F}_{2}$ population. Days to flowering seems to be controlled primarily by two genes having duplicate recessive epistasis under the short day conditions. 

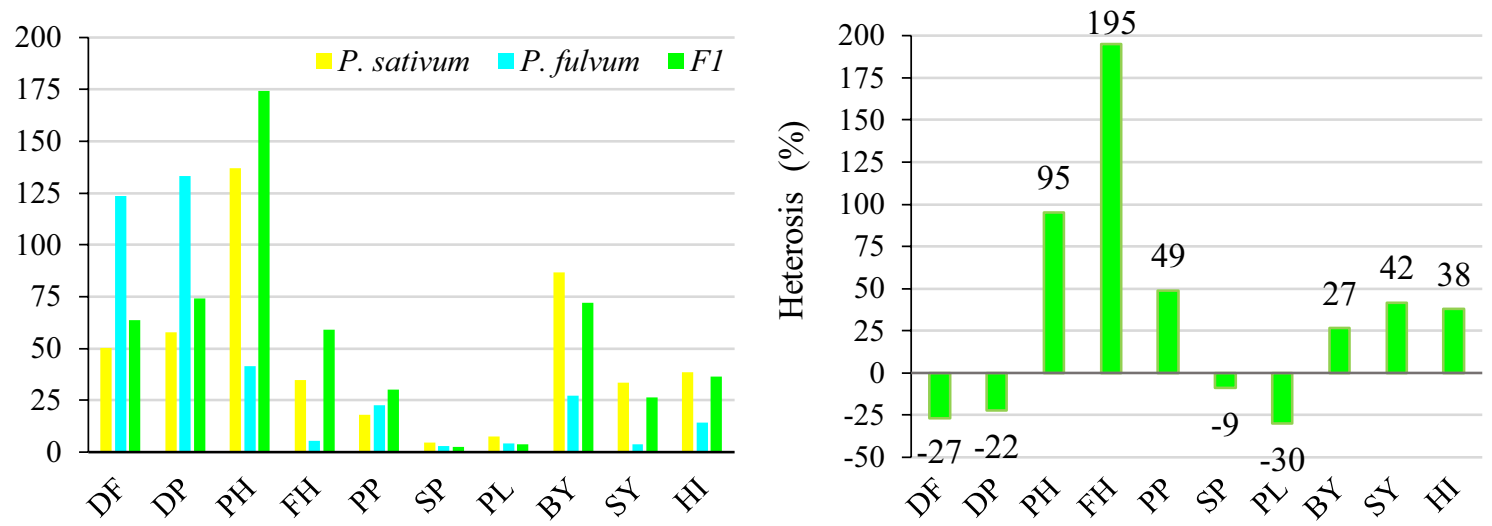

Figure 2. Comparison of agro-morphological traits in $\mathrm{F}_{1}$ derived from interspecific crosses $P$. sativum $\times P$. fulvum and their parents (left) and heterosis values (\%) of $\mathrm{F}_{1}$ plants (right). (DF is days to flowering, DP is days to pod setting, $\mathrm{PH}$ is plant height, $\mathrm{FH}$ is first pod height, $\mathrm{PP}$ is number of pods per plant, $\mathrm{SP}$ is number of seeds per plant, PL is pod length, BY is biological yield, SY is seed yield, HI is harvest index).

\begin{tabular}{|c|c|c|c|c|c|c|c|c|c|c|c|}
\hline \multirow[b]{2}{*}{ Traits } & \multicolumn{2}{|l|}{ ACP 20} & \multicolumn{2}{|l|}{ AWP 600} & \multicolumn{2}{|l|}{$\mathrm{F}_{1}$} & \multicolumn{2}{|l|}{$F_{2}$} & \multicolumn{2}{|l|}{$F_{3}$} & \multirow{2}{*}{$\begin{array}{l}h^{2} \\
(\%)\end{array}$} \\
\hline & Min-Max & $\overline{\mathrm{X}} \pm \mathrm{S}_{\overline{\mathrm{X}}}$ & Min-Max & $\overline{\mathrm{X}} \pm \mathrm{S}_{\overline{\mathrm{X}}}$ & Min-Max & $\overline{\mathrm{X}} \pm \mathrm{S}_{\overline{\mathrm{X}}}$ & Min-Max & $\overline{\mathrm{X}} \pm \mathrm{S}_{\overline{\mathrm{X}}}$ & Min-Max & $\overline{\mathrm{X}} \pm \mathrm{S}_{\overline{\mathrm{X}}}$ & \\
\hline Days to flowering (DF) & $48.0-52.0$ & $50.3 \pm 1.2$ & $119.0-127.0$ & $123.7 \pm 2.4$ & $63.0-64.0$ & $63.5 \pm 0.3$ & $17.0-96.0$ & $58.6 \pm 1.9$ & $13.0-180.0$ & $97.4 \pm 4.7$ & 82 \\
\hline Days to podding (DP) & $55.0-60.0$ & $57.7 \pm 1.4$ & $128.0-139.0$ & $133.3 \pm 3.2$ & $73.0-75.0$ & $74.3 \pm 0.5$ & $29.0-103.0$ & $68.6 \pm 1.9$ & $18.0-188.0$ & $103.2 \pm 4.7$ & 80 \\
\hline Plant height (PH) & $134.0-142.0$ & $137.0 \pm 2.5$ & $39.0-43.0$ & $41.3 \pm 1.2$ & $167.0-178.0$ & $174.3 \pm 2.5$ & $16.0-244.0$ & $129.0 \pm 6.4$ & $7.0-252.0$ & $94.5 \pm 6.3$ & 45 \\
\hline First pod height (FH) & $33.0-36.0$ & $34.7 \pm 0.9$ & $5.0-6.0$ & $5.3 \pm 0.3$ & $51.0-64.0$ & $59.0 \pm 2.9$ & $2.0-102.0$ & $36.9 \pm 2.7$ & $1.0-92.0$ & $22.7 \pm 1.9$ & 45 \\
\hline No of pods per plant (PP) & $16.0-20.0$ & $18.0 \pm 1.1$ & $21.0-24.0$ & $22.7 \pm 0.9$ & $29.0-32.0$ & $30.3 \pm 0.6$ & $7.0-81.0$ & $41.3 \pm 2.0$ & $1.0-68.0$ & $18.5 \pm 1.1$ & 33 \\
\hline No of seed per pod (SP) & $4.0-5.0$ & $4.7 \pm 0.3$ & $3.0-3.0$ & $3.0 \pm 0.0$ & $2.0-3.0$ & $2.5 \pm 0.3$ & $1.0-4.7$ & $1.9 \pm 0.1$ & $1.0-5.0$ & $2.4 \pm 0.1$ & 50 \\
\hline Pod length (PL) & $7.0-8.0$ & $7.3 \pm 0.3$ & $4.0-4.5$ & $4.2 \pm 0.2$ & $3.7-4.3$ & $3.9 \pm 0.2$ & $2.7-7.7$ & $4.7 \pm 0.1$ & $1.0-8.0$ & $4.3 \pm 0.1$ & 36 \\
\hline Biological yield (BY) & $79.8-91.3$ & $86.5 \pm 3.4$ & $26.7-27.9$ & $27.2 \pm 0.3$ & $67.0-78.0$ & $72.0 \pm 2.7$ & $26.0-237.0$ & $124.5 \pm 6.1$ & $4.0-243.0$ & $75.0 \pm 4.9$ & 37 \\
\hline Seed yield (SY) & $24.8-40.2$ & $33.4 \pm 4.5$ & $3.7-4.3$ & $3.9 \pm 0.2$ & $23.0-30.0$ & $26.3 \pm 1.5$ & $10.0-83.0$ & $35.8 \pm 1.8$ & $4.2-79.8$ & $14.4 \pm 1.8$ & 28 \\
\hline Harvest index (HI) & $31.0-44.0$ & $38.3 \pm 3.8$ & $13.9-15.4$ & $14.4 \pm 0.5$ & $33.8-38.5$ & $36.4 \pm 1.0$ & $8.7-69.7$ & $31.8 \pm 1.5$ & $2.8-65.7$ & $22.6 \pm 0.9$ & 16 \\
\hline
\end{tabular}

Table 3. Minimum (Min) and maximum (Max) values, means $(\overline{\mathrm{X}}) \pm$ standard errors $\left(\mathrm{S}_{\overline{\mathrm{X}}}\right)$ and narrow-sense heritability $\left(h^{2}\right)$ for agro-morphological traits in parents and progeny derived from interspecific crosses $P$. sativum $\times$ P. fulvum.

While days to flowering of the de novo super early progeny in $\mathrm{F}_{4}$ were between 24 and 34 days, days to pod setting varied between 28 and 48 days. Days to flowering of de novo super early progeny in $\mathrm{F}_{5}$ was determined to be between 25 and 40 days and days to pod setting was between 30 and 47 days (Fig. 4). The de novo super early progeny occurred especially in the $\mathrm{F}_{2}$ and $\mathrm{F}_{3}$ populations, but not in the parents. De novo super early progeny flowered after 18 days in $\mathrm{F}_{2}$ population (Fig. 3a), and when segregated for earliness in the later generations, flowered after 25 days in $\mathrm{F}_{5}$ (Fig. 4). Some of the de novo super early progeny were selected for fresh green pod and seed in the $\mathrm{F}_{5}$ population (Fig. 1d,e).

Heritability. Narrow-sense heritability $\left(h^{2}\right)$ values were highest for days to flowering $(82 \%)$ and days to pod setting (80\%) (Table 3). While the narrow-sense heritability of the number of seeds per pod was 50 , the plant height and the first pod height were 45 . The heritability of biological yield, pod length, number of pods per plant, and seed yield were found to be $37 \%, 36 \%, 33 \%$ and $28 \%$, respectively. Harvest index had the lowest narrowsense heritability at $16 \%$ (Table 3 ).

Relationships between correlated traits and lines. Eigenvalues of the principal component analyses (PCAs) in the $\mathrm{F}_{2}$ population, were found to be greater than 1 for four components. However, the diagram explained $54.5 \%$ of the total variance with two components (Fig. 5a). PC1 was closely related to plant height $(\mathrm{PH})$, first pod height $(\mathrm{FH})$, number of pods per plant (PP) and biological yield (BY) at $37.3 \%$. PC2 was related to the number of seeds per pod (SP) and pod length (PL), representing $17.2 \%$ of the total variance. The third component was related to days to flowering (DF) and days to pod setting (DP) and explained $16.2 \%$ of the total variance. In addition, the progeny in the upper left part of the PCA diagram were those with earlier flowering and pod setting than the others (Fig. 5a). Considering the PCA results of the $\mathrm{F}_{3}$ population, it was divided into two components. The first component (PC1) was related to almost all traits (DF, DP, PH, FH, PP, BY and SY) with a variance of $42.39 \%$. PC2 represented $13.86 \%$ of the total variance with SP and PL traits (Fig. 5b). As in the 
a) $\mathrm{F}_{2}$

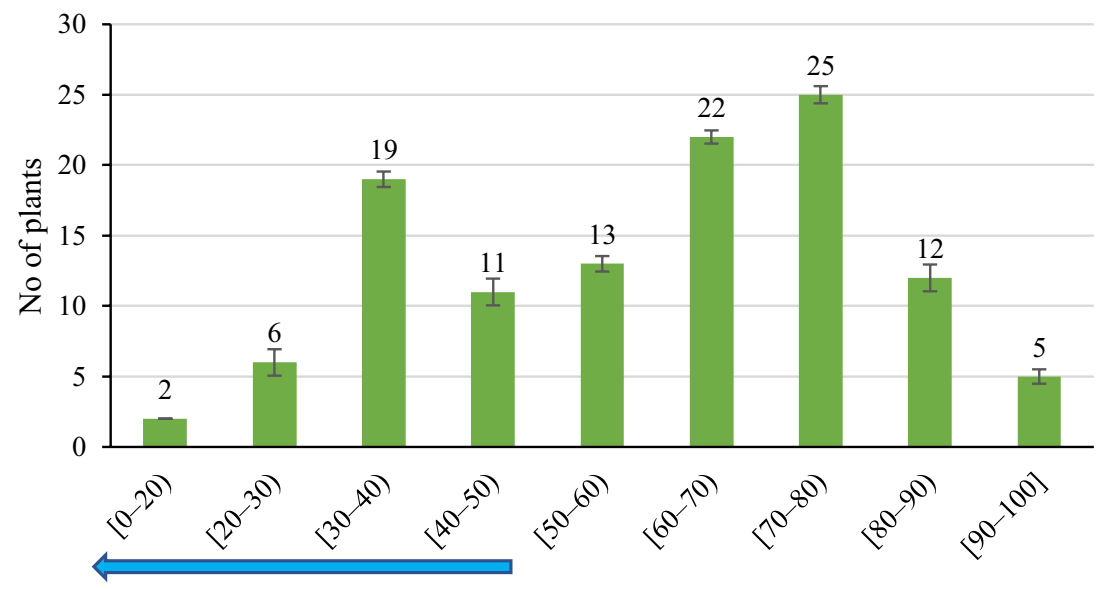

Transgressive segregations $<$ ACP 20

Days to flowering

\section{b) $\mathrm{F}_{3}$}

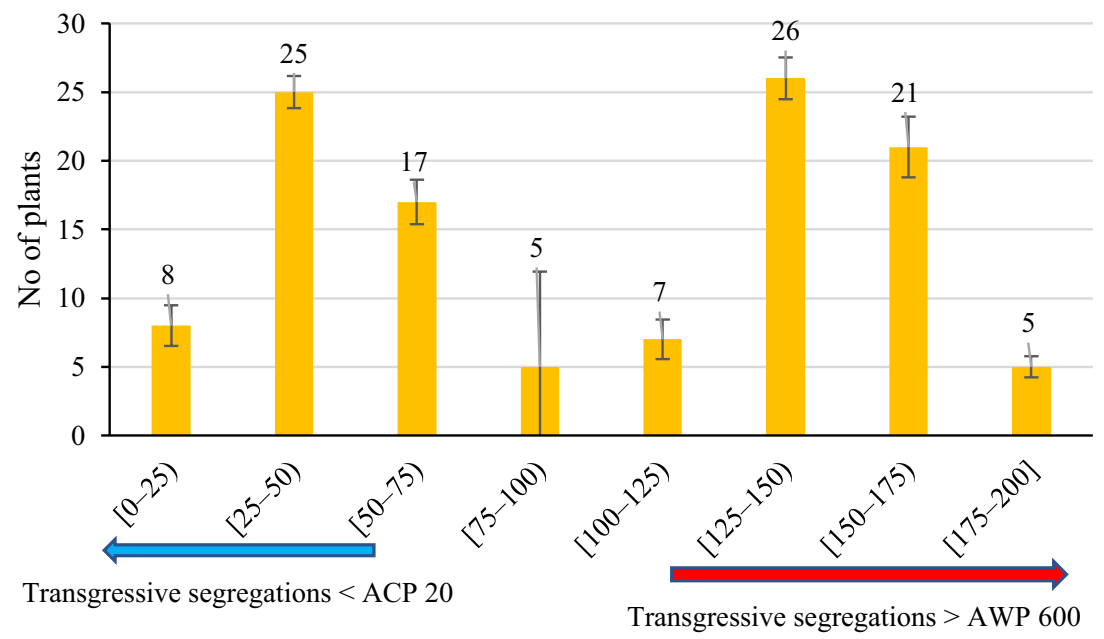

Days to flowering

Figure 3. Frequency distribution of days to flowering in $\mathrm{F}_{2}(\mathbf{a})$ and $\mathrm{F}_{3}(\mathbf{b})$ populations. Transgressive segregations were shown by arrows (blue and red colors). De novo super-early progeny are earlier than the earliest parent (Blue color).

$\mathrm{F}_{2}$ population, de novo super-early progeny in the $\mathrm{F}_{3}$ population were found in the upper left part of the PCA diagram (Fig. 5a,b).

Direct and indirect effects on agro-morphological traits over days to flowering. To examine the direct and indirect effects of agro-morphological traits on days to flowering, path (p) analysis was performed on the $\mathrm{F}_{3}$ population derived from inter-specific crosses $P$. sativum $\times P$. fulvum (Table 4 ). Days to pod setting and first pod height had statistically significant $(P<0.05)$ direct effects on days to flowering, and the coefficients were $p=0.999^{*}$ and $p=0.018^{\star}$, respectively. In addition, plant height with $p=-0.021^{\star}$ had negative direct effect on days to flowering. Plant height $\left(p=-0.498^{\star}\right)$, first plant height $\left(p=0.655^{\star}\right)$, pods per plant $\left(p=0.303^{\star}\right)$ and biological yield $\left(p=-0.288^{\star}\right)$ had significant indirect effect on days to flowering over days to pod setting (Table 4 ).

\section{Discussion}

Wild pea species are not only useful genetic resources for resistance to different a/biotic stresses ${ }^{37-52}$, but they also possess nutritional value for food and feed, desirable agronomic traits and advantages in nitrogen fixation ${ }^{53}$. Progeny have successfully been produced by interspecific crosses when $P$. fulvum was used as a pollen donor ${ }^{37,41,45,54} . P$. fulvum was reported in the second gene pool of the genus Pisum ${ }^{55}$. According to the available literature, reciprocal interspecific crosses were reported by Kosterin et al. ${ }^{56}$ as in the present study. 


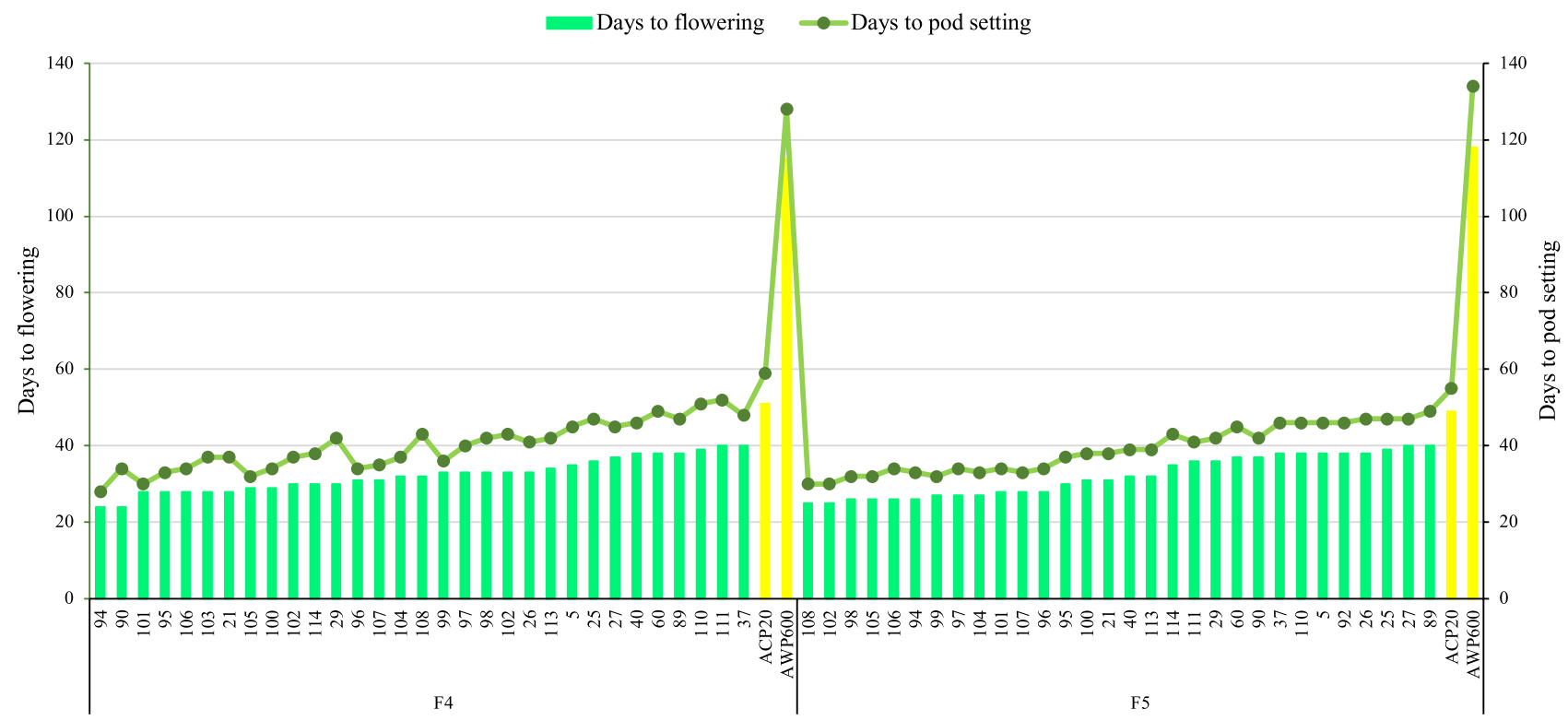

Figure 4. Days to flowering and days to pod setting of parents and de novo super-early progeny in $\mathrm{F}_{4}$ and $\mathrm{F}_{5}$ populations derived from interspecific crosses $P$. sativum $\times$ P. fulvum.

After hybridization, seed coat color and surface of the seed coat were recorded as black and round inside pods in P. sativum, mother or pollen receiver plant when P. fulvum species was used as a pollinator. A similar color and surface were found in $\mathrm{F}_{1}$ plants indicating that black seed color and round seed surface were dominant over their counterparts. Gregor Johann Mendel, known as the father of genetics, reported a similar finding on seed coat surface in intraspecific crosses in pea crop 156 years ago ${ }^{57}$. The flower color of both $\mathrm{F}_{1}$ plants was orange (Fig. 1) indicating that orange flower color was dominant over white flower color as reported by Kosterin et al. ${ }^{56}$. Kosterin et al. ${ }^{56}$ reported that flower color was quantitatively inherited in an $\mathrm{F}_{2}$ segregation population derived from reciprocal interspecific crosses $P$. sativum $\times$ P. fulvum and $P$. fulvum $\times$ P. sativum. However, flower color in one way interspecific crosses $P$. sativum $\times$ P. fulvum was segregated in the $\mathrm{F}_{2}$ population as three distinct categories with 12 (orange): 3 (fuchsia): 1(white colors) (Fig. 1a-c) segregation ratio (Table 2) inferring as dominant epistasis. Prior to the present study, interspecific crosses $P$. sativum $\times P$. fulvum were reported in several studies ${ }^{37,41,45,48,56,58-60}$, while hybrids $P$. fulvum $\times P$. sativum have been introduced in only research study to date ${ }^{56}$.

Negative average heterosis was obtained for days to flowering $(-27 \%)$ and days to pod setting $(-22.2 \%)$ traits (Fig. 2). Guindon et al. ${ }^{61}$ similarly found negative heterosis for days to flowering, as $0.48 \%$ heterosis for plant height, and $27 \%$ for the number of pods. In interspecific crosses, average heterosis was recorded for plant height (95\%), pods per plant (49\%), seed yield (42\%) and harvest index (38\%) that were important for yield (Fig. 2). However, traits including seeds per pod (-9\%) and pod length (-29.8\%) had negative average heterosis (Fig. 2). Sarawat et al. ${ }^{6}$ reported that heterosis was negative for seeds per pod $(-1.4 \%)$ and 100 -seed weight $(-2.1 \%)$, while days to flowering (earliness) at $1.4 \%$, plant height at $19.2 \%$, seed yield at $30.8 \%$, pods per plant at $38.5 \%$ and harvest index at $0.6 \%$ had positive heterosis.

Not only in the $\mathrm{F}_{2}$ population but also in the $\mathrm{F}_{3}$ population, transgressive segregations were investigated for agro-morphological traits. However, differences between maximum and minimum values for some agromorphological traits were declined in the $\mathrm{F}_{3}$ population indicating that transgressive segregations were reduced from $\mathrm{F}_{2}$ to $\mathrm{F}_{3}$ population (Table 3 ). The term of transgressive segregation was coined as a phenomenon specific to segregating generations and refers to the fraction of progeny that exceeds the parents in either a negative or positive direction ${ }^{34-36}$. This phenomenon is similar to heterosis in first-generation hybrids. Rieseberg et al. ${ }^{36}$ defined the creation of transgressive segregations as: (1) mutation frequency in segregating populations; (2) reduced developmental stability; (3) non-additive allelic effects between loci or epistasis; (4) non-additive allelic effects within a locus or overdominance; (5) the unmasking of some recessive alleles that are generally heterozygous in the parents; (6) variation in chromosome number; and (7) the complementary action of additive alleles that are dispersed between the parents. In the present study, except for mutation frequency and variation in chromosome number, five reasons for transgressive segregations in $\mathrm{F}_{2}$ and $\mathrm{F}_{3}$ populations could be considered. Flowering time in pea has been considered to be two genetic control systems as a result of an increase in recessive genes for early flowering, and dominant genes for late flowering ${ }^{63}$. Earliness in pea crosses was related with additive and nonadditive genetic effects ${ }^{64,65}$. Transgressive segregations in segregating generations in interspecific crosses in Cicer species have been previously outlined ${ }^{66,67}$. One of the main objectives of most breeding studies is to increase yield, but it is a challenge for breeders to achieve an increase because the yield is affected by genes and environments due to its polygenic nature. Therefore, it is important to benefit from the genetic variations in segregating populations. For example, seed yield is a critical characteristic in terms of yield and this value was recorded as maximum $33.4 \mathrm{~g}$ in the best parent (female parent), while it was recorded as $83 \mathrm{~g}$ in the $\mathrm{F}_{2}$ population, more than twice that of the parent (Table 3). Farmers prefer varieties with higher biological yields for forage. In such cases, genotypes 


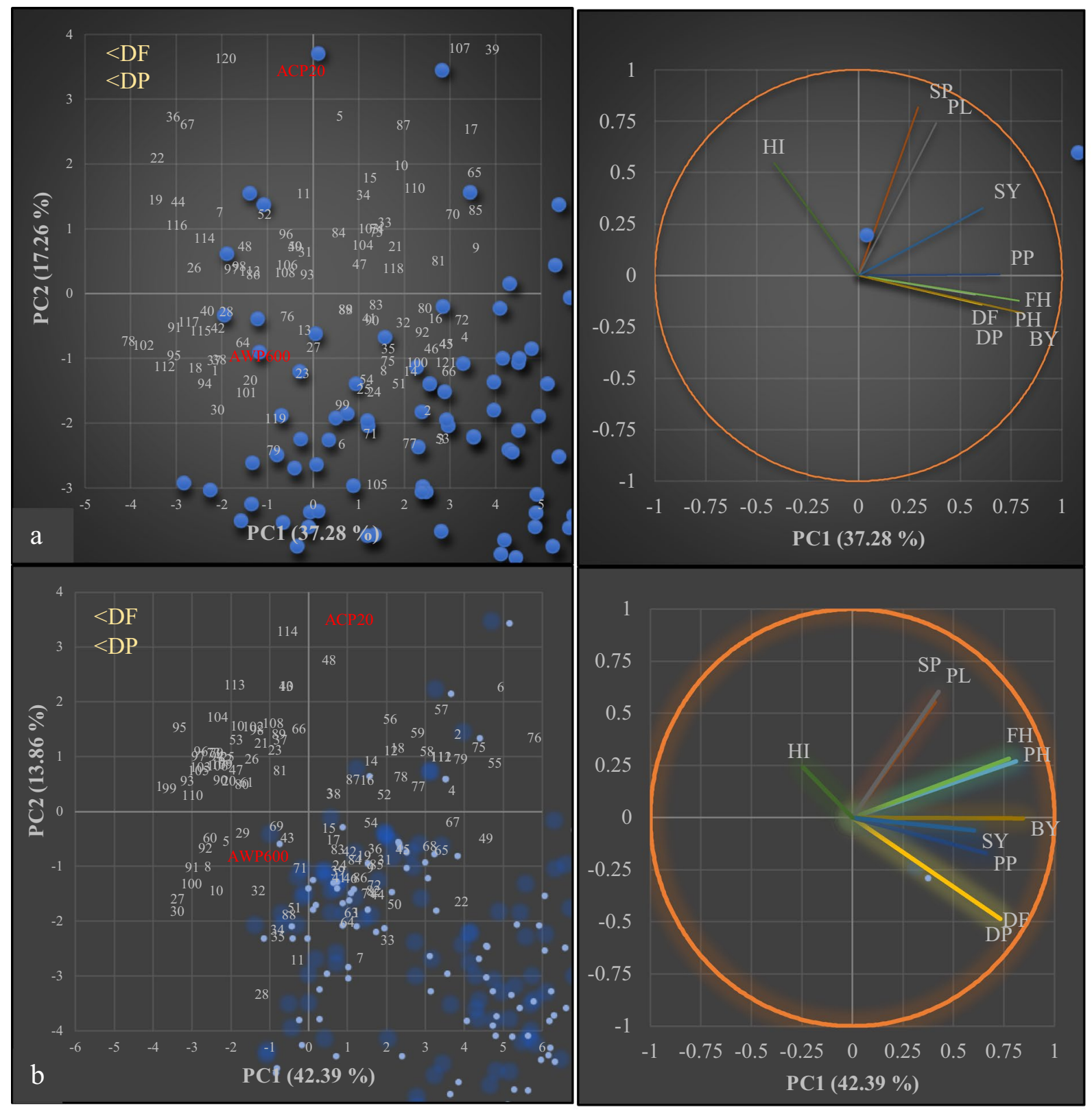

Figure 5. Principal component analyses (PCAs) for in $\mathrm{F}_{2}(\mathbf{a})$ and $\mathrm{F}_{3}(\mathbf{b})$ populations derived from interspecific crosses $P$. sativum $\times P$. fulvum. Each blue dot represents a progeny in $\mathrm{F}_{2}$ and $\mathrm{F}_{3}$ populations. (DF is days to flowering, DP is days to pod setting, PH is plant height, FH is first pod height, $\mathrm{PP}$ is number of pods per plant, SP is number of seeds per plant, PL is pod length, BY is biological yield, SY is seed yield, HI is harvest index).

that produce more vegetative parts rather than seeds are selected. The maximum biological yield in the $\mathrm{F}_{2}$ and $\mathrm{F}_{3}$ populations was found to be $237 \mathrm{~g}$ and $243 \mathrm{~g}$, respectively, which is almost 3 times higher than the best parent.

De novo early progeny was found in segregated populations (Fig. 3, 4 and Table 3). Two progeny flowered in 18 days in $\mathrm{F}_{2}$ population (Table 2), whereas progeny from these two progeny flowered in 13 days in $\mathrm{F}_{3}$ (Fig. 3 and Table 3). According to the results of the literature review, no study has reported peas that flowered in 13 days. The use of wild peas in crossbreeding studies has been reported by many researchers to increase genetic diversity ${ }^{51,68-70}$, and a wide variation has been reported in the flowering time of pea crop ${ }^{12-14}$. Watts et al ${ }^{71}$ reported that the flowering time of pea was between 52 and 71 days. Vanhala et al. ${ }^{15}$ determined flowering time in the range of 32.4-87.2 days in a study which researched the adaptation of pea flowering time. Days to flowering was reported to be 31-49, 46-54 and 46-54 days at different years or locations under $18 \mathrm{~h}$ photoperiod conditions in crosses $P$. sativum $\times$ P. fulvum by Jha et al. ${ }^{60}$. In the present study, days to flowering was recorded under short day conditions with daily sun hours (day length) between $2-9 \mathrm{~h}$ (Fig. 6). Earliness was induced by long light period under controlled conditions and six generations were advanced via speed breeding in pea ${ }^{10,11}$. If de novo super early lines (Fig. 4) can be grown under suitable conditions, it is considered that 8-10 generations per year can be obtained. The earliest progenies in the $\mathrm{F}_{2}$ population were 3 times earlier than the mean of the 


\begin{tabular}{|c|c|c|c|c|c|c|c|c|c|}
\hline Traits & DP & PH & FH & PP & SP & PL & BY & SY & HI \\
\hline DP & $0.999^{*}$ & -0.117 & 0.165 & 0.190 & -0.124 & 0.132 & 0.139 & -0.058 & -0.07 \\
\hline $\mathrm{PH}$ & $-0.498^{\star}$ & $-0.021^{*}$ & $0.840^{*}$ & $0.674^{*}$ & -0.178 & 0.447 & 0.295 & -0.390 & -0.307 \\
\hline $\mathrm{FH}$ & $0.655^{\star}$ & $0.786^{*}$ & $0.018^{\star}$ & $-0.642^{*}$ & 0.290 & -0.101 & 0.208 & 0.103 & 0.253 \\
\hline $\mathrm{PP}$ & $0.303^{*}$ & $0.254^{*}$ & $-0.258^{*}$ & 0.003 & $0.321^{*}$ & $-0.313^{*}$ & 0.164 & $0.409^{*}$ & -0.260 \\
\hline SP & -0.103 & -0.035 & 0.061 & 0.167 & -0.001 & $0.326^{*}$ & -0.026 & 0.036 & 0.004 \\
\hline $\mathrm{PL}$ & 0.118 & 0.094 & -0.023 & -0.175 & $0.350^{*}$ & 0.003 & -0.035 & 0.143 & 0.108 \\
\hline BY & $0.288^{*}$ & 0.144 & 0.109 & 0.213 & -0.065 & -0.082 & 0.001 & $0.551^{*}$ & 0.087 \\
\hline SY & -0.075 & -0.120 & 0.034 & 0.334 & 0.057 & 0.209 & $0.347^{*}$ & -0.002 & -0.052 \\
\hline $\mathrm{HI}$ & -0.055 & -0.053 & 0.047 & -0.120 & 0.004 & 0.089 & 0.031 & -0.029 & 0.00 \\
\hline
\end{tabular}

Table 4. Path coefficient showing direct (bold) and indirect effects for agro-morphological traits on days to flowering (DF) in $\mathrm{F}_{3}$ population advanced from interspecific crosses $P$. sativum $\times$ P. fulvum. DP is days to pod setting, PH is plant height, FH is first pod height, PP is number of pods per plant, SP is number of seeds per plant, PL is pod length, BY is biological yield, SY is seed yield, HI is harvest index. ${ }^{\star}$ Indicates significant relationships at $P<0.05$.

a) $2017-2018\left(\mathrm{~F}_{2}\right)$

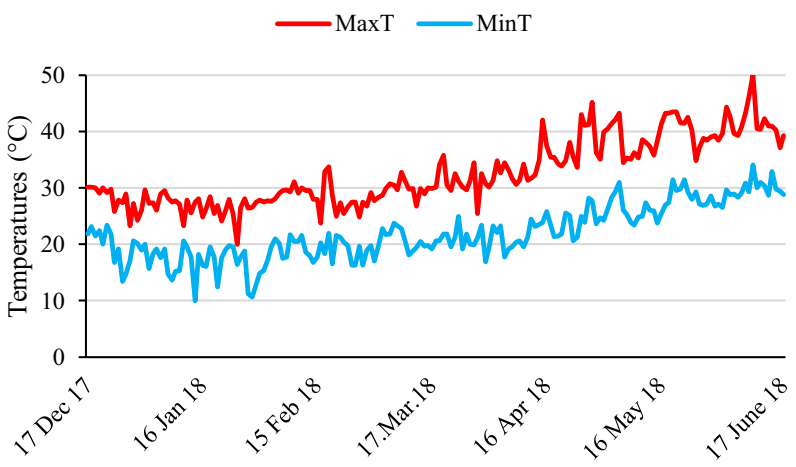

c) $2019-2020\left(\mathrm{~F}_{4}\right)$

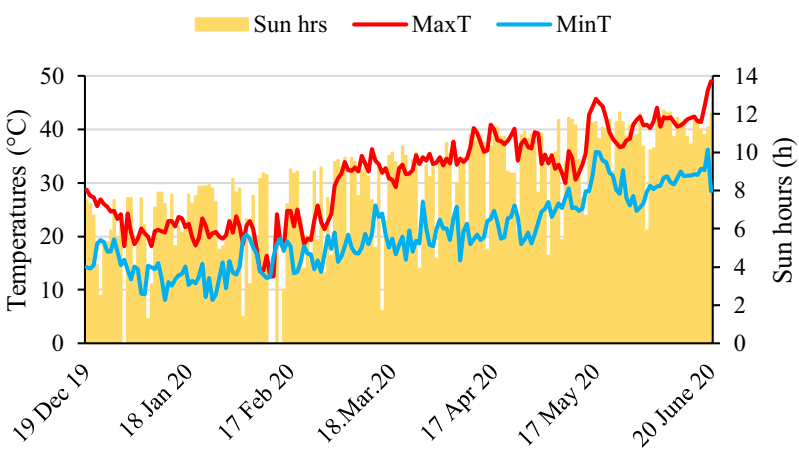

b) $2018-2019\left(\mathrm{~F}_{3}\right)$

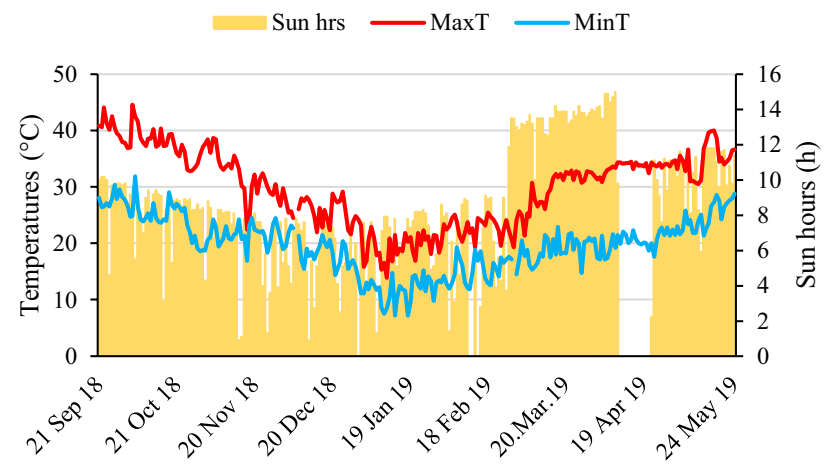

d) $2020-2021\left(\mathrm{~F}_{5}\right)$

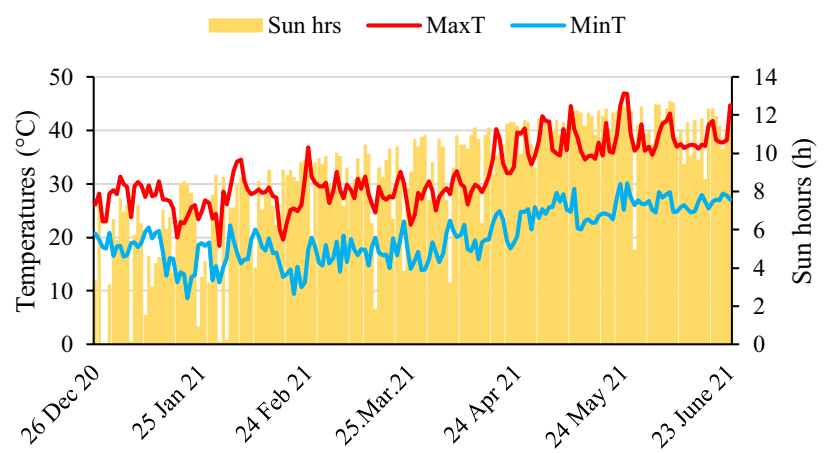

Figure 6. Daily minimum (MinT), maximum (MaxT) temperatures and daily sun hours in the glasshouse in 2017-18 (a), 2018-19 (b), 2019-20 (c) and 2020-21 (d).

female parent and 7.5 times earlier than the mean of the male parent in terms of the number of days to flowering and pod setting (Table 3 and Fig. 3). The earliest progeny in the $\mathrm{F}_{3}$ population were 3.9 times earlier than the mean of the female parent and 9.5 times earlier than the mean of the male parent in terms of the number of days to flowering and pod setting (Table 3 and Fig. 3). $F_{2}$ and $F_{3}$ populations have shown bimodal distribution for flowering time as a segregation ratio of late to early flowering of 9:7 (Fig. 3a,b). Under short-day conditions, this distribution demonstrated that flowering time is controlled by two genes with duplicate recessive epistasis or complementary gene action. Similar findings on 9:7 distribution for flowering time were reported by in $\mathrm{F}_{2}$ population derived from the intraspecific crosses in pea ${ }^{27}$ and chickpea ${ }^{72}$. A bimodal distribution, late and early, was discovered for the flowering node using $\mathrm{F}_{2}$ population in pea, and the gene responsible for the late flowering was named $\mathrm{Sn}^{73}$. Snsn gene pair was responsible for the difference between early and late flowering in intraspecific pea crosses ${ }^{74}$. Approximately 20 loci were pointed out to be involved in pea flowering variation ${ }^{29}$, 
with cultivated alleles usually resulting in early flowering and a decline in photoperiod response ${ }^{75} . H r, S n, E$, and $L f$ genes were found to be effective in naturally occurring variation ${ }^{29}$. $H r$, on the other hand, has just one naturally existing mutant allele, whereas $S n$ has both naturally occurring and induced mutant alleles ${ }^{76}$. In short day conditions, $h r$ was reported to be induced early flowering and decreased of the response to photoperiod but not whole loss, while $s n$ was indicated to be caused complete daylength insensitivity ${ }^{22}$. Dominant alleles of $E$ have been stated to cause early flowering and this effect had complex interactions with other loci ${ }^{29}$. Flowering was inhibited on both long and short days conditions by $L f$, while accessions having $L f$ gene was inactivated by the nonsense mutation providing extreme earliness ${ }^{21,22}$. The extreme earliness identified in the present study is considered to be due to variants of $L f$ gene.

There is increasing global concern about the impact of climate change on food production, livelihoods, and food security ${ }^{77,78}$. Global warming is anticipated to be one of the biggest hazards for food and it will have adverse effects on agricultural production. It is estimated that the expected world population will be 8 billion by 2030 , which will require an increase of $60 \%$ in the current food production ${ }^{79,80}$. The vast majority of the world's population lives in cities and given the reasons for migration from rural areas to the city, it is inevitable that the consumption rate will create even more food deficits ${ }^{78}$. According to the Intergovernmental Panel on Climate Change (IPCC), global warming will exceed $1.5^{\circ} \mathrm{C}$ by 2030 , leading to permanent loss of the most sensitive ecosystems and crisis for vulnerable people and societies in underdeveloped and developing countries ${ }^{81}$. Drought and heat stresses, which create abiotic stressors that significantly reduce the yield of plants, will be the leading causes of global warming in agriculture ${ }^{82}$. Drought and heat effects are expected to increase with climate change and increasing water shortages ${ }^{83}$. Two types of heat stress in agricultural areas are (1) heat shock, which occurs in daytime and lethal temperatures, and (2) moderate heat, which is higher than optimum temperature in daytime or at night ${ }^{83}$. Since pea cultivation is carried out in rainfed areas in some parts of the world, plants suffer from heat stress. Plants exhibit three different mechanisms for heat tolerance, namely, heat escape, heat tolerance and heat avoidance ${ }^{84}$. Heat escape enables plants to quickly complete their life cycle in a short time and under favorable conditions and in this way, plants tend to escape drought due to early maturity ${ }^{18,85}$. Early flowering genotypes in pea play a crucial role in minimizing bottlenecks such as abiotic and biotic stresses and can lower production costs as a result of low input. De novo super early progeny was seen to have the ability to escape from heat stresses, while late flowering progeny were subjected to heat stresses during flowering and pod setting (Fig. 6). Vegetable types were not only high yielding but also free of any known undesirable traits of the wild species, such as pod dehiscence and non-uniform maturity (Fig. 1).

In addition to problems such as global warming, pandemics that cause the death of thousands of people, such as COVID-19, also adversely affect the world ${ }^{86}$. In vulnerable countries where hunger and malnutrition are already common, pandemics such as COVID-19 also pose a threat to food safety and scarcity ${ }^{87}$. Hunger, malnutrition, and unbalanced nutrition affect more than 820 million people worldwide, and approximately 150 million children are negatively affected by an irregular diet ${ }^{88}$. At the beginning of the COVID-19 outbreak, there was an excessive demand for food in the world ${ }^{89}$. Food deficit is a major problem in such pandemics and thus early varieties play an important role in meeting these food needs. Very early pea progeny, which can be obtained in about one month, will be a unique food source able to meet food needs in a short time.

According to the heritability classification of high ( $>50 \%)$, medium $(30-50 \%)$ and low $(<30 \%)$ described by Guindon et al. ${ }^{61}$, days to flowering and pod setting had high values of narrow sense heritability (Table 3 ). The high values of narrow sense heritability means that the gain from selection can be achieved by selecting de novo super early progeny. In the present study, days to flowering in de novo super early progeny was fixed with days to flowering of 24-25 days in $\mathrm{F}_{4}$ and $\mathrm{F}_{5}$ populations (Fig. 4). Guindon et al. ${ }^{61}$ reported that the number of flowering days, number of pods, pod length and number of seeds per pod had high values of heritability, but not plant height. Singh et al. ${ }^{90}$ found high broad sense heritability in pea for days to flowering, and days to pod setting. Since earliness in the present study was seen to have high heritability, success can be achieved in selection in early generations.

Based on principal component analyses (PCAs), earliness including days to flowering and pod setting was related in both $\mathrm{F}_{2}$ and $\mathrm{F}_{3}$ populations (Fig. 5). Seed yield was correlated with pods per plant, in accordance with the findings of Guindon et al. ${ }^{61}$ and Esposito et al. ${ }^{11}$. According to the available literature, this is the first path analysis on days to flowering in interspecific crosses P. sativum $\times$ P. fulvum. Days to pod setting, plant height, and first pod height had statistically significant direct effects on days to flowering (Table 4). Path analysis performed in the $\mathrm{F}_{2}$ population obtained from intraspecific crosses by Singh et al. ${ }^{90}$, showed that plant height and pods per plant had a direct positive effect on seed yield, and a direct negative effect on days to flowering. Similar findings were reported by Singh and Srivastava ${ }^{92}$ and Tiwari et $\mathrm{a}^{93}$. In the present study, biological yield and pods per plant had a significant effect on seed yield (Table 4) indicating that seed yield selection should be carried out according to biological yield and pods per plant.

In presenting the results obtained in the present study, the following can be suggested for readers; (1) Not only transgressive segregations but also de novo super early progeny were obtained by interspecific crosses between the cultivated pea (P. sativum) and its wild relative P. fulvum. (2) Some de novo super early progeny flowered in 24-25 days in both $\mathrm{F}_{4}$ and $\mathrm{F}_{5}$ generations. (3) The heritability was found to be high in the present study since the earliness trait was little affected by the environment. It can be suggested that traits with high heritability will yield successful results in early generation selection studies. (4) De novo super early progeny obtained from interspecific crosses in the breeding study matured without exposure to heat stress and this progeny can escape from heat stress. (5) It is thought that by using de novo super early progeny obtained in breeding studies, peas with a short vegetation period can be grown without the risk of frost exposure in the northern hemisphere. (6) Green pods and seeds of garden pea are important vegetables in Mediterranean cuisine and they have a high price in markets with earliness whenever the crop is purchased by consumers in autumn. (7) It has also been understood that de novo super early progeny can also be cultivated at high altitude without the risk of frost. (8) It 
is estimated that much more than six generations in a year under suitable conditions can be obtained via de novo super early progeny. This shows that these de novo super early progeny can be alternative and complementary materials to the speed breeding approach. (9) This study can be considered an example study for the use of wild peas in breeding studies. (10) Useful progeny obtained from crossing wild species with cultivated species reveal the importance of wild species.

\section{Materials and method}

Parents. ACP 20 is the cultivated genotype of $P$. sativum with mid-early flowering and white flowers, whereas AWP 600 is a wild genotype of P. fulvum with late flowering and orange flower color. According to our records, ACP 20 is a landrace grown as vegetable in Antalya, Turkey, while AWP 600 is originated from Turkey and received from USDA GRIN, USA. The plant materials comply with relevant institutional, national and international guidelines and legislations. As seen in Table 1, ACP 20 has large, cream-colored seeds and weight of $42.8 \mathrm{~g}$ per 100 seeds. AWP 600 has small, black-colored seeds and weight of 5.4 g per 100 seeds. It is resistant to seed beetle (Callosobruchus chinensis L.) and powdery mildew caused by Erysiphe pisi DC ${ }^{37,38}$. Both parents, ACP 20 and AWP 600, were grown on the campus of Akdeniz University, Antalya, Turkey $\left(30^{\circ} 38^{\prime} \mathrm{E}, 36^{\circ} 53^{\prime} \mathrm{N}, 33 \mathrm{~m}\right.$ above sea level) as a spring-sown crop in 2015.

Progeny. Reciprocal interspecific crosses $P$. sativum $\times$ P. fulvum and $P$. fulvum $\times$ P. sativum were performed. All progeny derived from interspecific crosses $P$. sativum $\times P$. fulvum were advanced from $\mathrm{F}_{1}$ to $\mathrm{F}_{5}$ (Fig. 1 ), while $P$. fulvum $\times P$. sativum interspecific crosses were advanced up to $\mathrm{F}_{1}$ since only one $\mathrm{F}_{1}$ plant was obtained. $P$. fulvum $\times$ P. sativum interspecific cross was excluded from the study due to insufficient plants in $\mathrm{F}_{2}$ population.

$\mathrm{F}_{1}, \mathrm{~F}_{2}, \mathrm{~F}_{3}, \mathrm{~F}_{4}$ and $\mathrm{F}_{5}$ populations derived from interspecific crosses $P$. sativum $\times$ P. fulvum were sown on 14 December 2016, 17 December 2017, 21 September 2018, 19 December 2019 and 26 December 2020, respectively. Harvesting was applied individually as single plants. Each line was advanced as five seeds after $\mathrm{F}_{2}$ population. From the $\mathrm{F}_{3}$ to the $\mathrm{F}_{5}$, each line was advanced as a family consisting of five individuals.

De novo super-early progeny. Transgressive segregation was defined as the occurrence of progeny with values greater or less than the values of their parents (male and female plants) in segregated generations ${ }^{35}$. These extreme phenotypes are a major mechanism by which extreme or novel adaptations develop ${ }^{34-36}$. Different explanations have been provided to take into account the presence of extreme phenotypes in segregating populations ${ }^{94,95}$. However, de novo super-early progeny is here referred to as progeny with flowering or pod setting and maturity much earlier than the early parent (best parent) in segregating generations.

Agro-morphological traits. The following phenological traits were recorded in male and female plants and progeny derived from interspecific crosses P. sativum $\times$ P. fulvum. Days to flowering (DF) was recorded as the number of days after germination until the first flowering. Days to pod setting (DP) was recorded as the number of days after germination until the first pod setting. De novo super-early plants were individually harvested and advanced as single plant progeny.

The following agro-morphological traits were recorded on single plant in $\mathrm{F}_{1}$ and $\mathrm{F}_{2}$, while they were obtained from average of five plants from $\mathrm{F}_{3}$ to $\mathrm{F}_{5}$. Plant height $(\mathrm{PH})$ and first pod height $(\mathrm{FH})$ were recorded in $\mathrm{cm}$ as the height of a plant from the ground to the top of the plant and as the height from ground to the first pod, respectively. Pods per plant (PP) and seeds per pod (SP) were recorded as total number of pods per plant and seeds per pod, respectively. Pod length (PL) was recorded in $\mathrm{cm}$ as the length of a pod. Biological yield (BY) was recorded in grams (g) as the total weight of a plant after harvest, while seed yield (SY) was recorded in $\mathrm{g}$ as the weight of seeds per plant after harvest. Harvest index (HI) was calculated as a percentage (\%), as the ratio of seed yield per plant to biological yield per plant multiplied by 100. For the pod length, three randomly selected pods on each plant were used and the number of seeds per pod trait of the same pods were recorded. Agro-morphological traits were recorded in $\mathrm{F}_{1}, \mathrm{~F}_{2}$ and $\mathrm{F}_{3}$ progeny and the parents. In the $\mathrm{F}_{4}$ and $\mathrm{F}_{5}$ populations, days to flowering and days to pod setting were recorded only in early lines and their parents.

Soil analyses. According to the soil analysis of the experimental field, it was determined that nitrogen and organic matter content were low, $\mathrm{pH}$ was found to be as high as 7.62 , whereas $\mathrm{CaCO}_{3}$ was $26.8 \%$. Although iron and zinc contents were considered to be deficient due to the high $\mathrm{pH}$ of the soil, other plant nutrition elements were generally considered to be balanced.

Daily minimum and maximum temperatures and sun hours in glasshouse. The minimum (MinT) and maximum (MaxT) daily temperatures and daily sun hours (h) in the glasshouse were presented in Fig. 6. The MaxT of the glasshouse were recorded as $50.1^{\circ} \mathrm{C}, 41.5^{\circ} \mathrm{C}, 47.3^{\circ} \mathrm{C}$ and $46.8^{\circ} \mathrm{C}$ for $2017-18,2018-19$, 2019-20 and 2020-21, respectively (Fig. 6).

Agronomic practices. A drip-irrigation system was used and plants were irrigated with well water at threeday intervals to avoid drought stress. Weed control was performed by hand. Fertilization was not applied because the plants supplied $80 \%$ of the nitrogen requirement ${ }^{55}$.

Heterosis. Hybrid vigor or average heterosis $\left(\mathrm{H}_{\mathrm{A}}\right)$ estimated for agro-morphological traits in order to test general combining ability between parents was calculated as: 


$$
H_{A}(\%)=\frac{F_{1}-M P}{M P} \times 100,
$$

where $F_{1}$ is from data of $F_{1}$ plants and MP is the mean of the two parents as mid-parent ${ }^{66}$.

Narrow-sense heritability. Narrow-sense heritability $\left(h^{2}\right)$ performed to explain inheritance of agro-morphological traits was calculated for days to flowering, days to podding and important agro-morphological traits, according to the progeny-parent regression method reported by Poehlman and Sleper ${ }^{96}$.

$$
\begin{aligned}
& b=\sum(X-\bar{X})(Y-\bar{Y}) / \sum(X-\bar{X})^{2}, \\
& h^{2}=b
\end{aligned}
$$

where $b$ is the regression coefficient of the offspring $\left(\mathrm{F}_{3}\right)$ value $(\mathrm{Y})$ to the representing parent $\left(\mathrm{F}_{2}\right)$ value $(\mathrm{X})$. Accordingly, the slope $(b)$ of the regression line represents the values of narrow-sense heritability. A similar narrow-sense heritability for agro-morphological traits was given in interspecific and intraspecific crosses in Cicer species $^{66}$. Narrow-sense heritability was given as a percentage (\%).

Chi-square analyses for flower color and flowering time. Chi square test $\left(\chi^{2}\right)$ was performed to estimate the goodness of fit to the expected ratio in the segregating $\mathrm{F}_{2}$ population using a following formula:

$$
\chi^{2}=\sum \frac{(O-E)^{2}}{E}
$$

where $O$ and $E$ in this formula represent the observed and expected values, respectively ${ }^{97}$.

Statistical analyses. All data were reported as descriptive statistics including mean, range and standard error values using SPSS 26.0 software (IBM SPSS: Chicago, IL, USA). The regression slope for days to flowering, days to pod setting and agro-morphological traits was calculated using SPSS 26.0 software. Path analysis was also performed to show direct and indirect relationships between days to flowering (earliness) and agromorphological traits. Principal component analyses (PCAs) were performed using XLSTAT statistical software Version 2016.02 (Addinsoft, Paris).

Received: 23 April 2021; Accepted: 23 September 2021

Published online: 05 October 2021

\section{References}

1. Food and Agriculture Organization. [Online] Available at: http://faostat.fao.org (Accessed 04 April 2021). FAO, Rome (2020).

2. Elzebroek, A. T. G. \& Wind, K. Guide to Cultivated Plants (CABI, 2008).

3. Cousin, R. Peas (Pisum sativum L.). Field Crop Res. 53(1-3), 111-130 (1997).

4. Liu, R. et al. Marker-trait association analysis of frost tolerance of 672 worldwide pea (Pisum sativum L.) collections. Sci. Rep. 7(1), $1-10$ (2017).

5. Ladizinsky, G. \& Abbo, S. The Search for Wild Relatives of Cool Season Legumes. (eds. La Ladizinsky, G. \& Abbo, S.) (Springer, 2015).

6. Knight, J. D. Frequency of field pea in rotations impacts biological nitrogen fixation. Can. J. Plant Sci. 92(6), 1005-1011 (2012).

7. Hu, F. et al. Strip width ratio expansion with lowered $\mathrm{N}$ fertilizer rate enhances $\mathrm{N}$ complementary use between intercropped pea and maize. Sci. Rep. 10(1), 1-11 (2020).

8. Chen, C. et al. Winter pea and lentil response to seeding date and micro-and macro-environments. Agron. J. 98(6), 1655-1663 (2006).

9. Sarrantonio, M. Northeast Cover Crop Handbook (Rodale Institute, 1994).

10. Ghosh, S. et al. Speed breeding in growth chambers and glasshouses for crop breeding and model plant research. Nat. Protoc. 13(12), 2944 (2018).

11. Watson, A. et al. Speed breeding is a powerful tool to accelerate crop research and breeding. Nat. plants 4(1), 23 (2018).

12. Levy, Y. Y. \& Dean, C. The transition to flowering. Plant Cell 10, 1973-1990 (1998).

13. Colasanti, J. \& Sundaresan, V. ‘Florigen’ enters the molecular age: Long-distance signals that cause plants to flower. Trends Biochem. Sci. 25, 236-240 (2000).

14. Weller, J. L. et al. Update on the genetic control of flowering in garden pea. J. Exp. Bot. 60(9), 2493-2499 (2009).

15. Vanhala, T. et al. Flowering time adaption in Swedish landrace pea (Pisum sativum L.). BMC Genet. 17(1), 117 (2016).

16. Clark, A. Managing cover crops profitably. In Sustainable Agriculture Research and Education Program Handbook Series (ed. Clark, A.) (College Park, 2007).

17. Levitt, J. Responses of plants to environmental stress. In Chilling, Freezing, and High Temperature Stresses (ed. Levitt, J.) 23-64 (Academic Press, 1980).

18. Shavrukov, Y. et al. Early flowering as a drought escape mechanism in plants: How can it aid wheat production?. Front. Plant Sci. 8, 1950 (2017).

19. Ellis, T. H. N. \& Poyser, S. J. An integrated and comparative view of pea genetic and cytogenetic maps. New Phytol. 153(1), 17-25 (2002).

20. Berry, G. J. \& Aitken, Y. Effect of photoperiod and temperature on flowering in pea (Pisum sativum L.). Funct. Plant Biol. 6(6), 573-587 (1979).

21. Foucher, F. et al. Determinate and late flowering are two terminal flower1/centroradialis homologs that control two distinct phases of flowering initiation and development in pea. Plant Cell 15, 2742-2754 (2003).

22. Murfet, I. The influence of genes ar and $\mathrm{n}$ on senescence in Pisum sativum L. Ann. Bot. 55, 675-683 (1985)

23. Weeden, N. F. Genetic changes accompanying the domestication of Pisum sativum: Is there a common genetic basis to the 'Domestication Syndrome' for legumes?. Ann. Bot. 100(5), 1017-1025 (2007).

24. Bordat, A. et al. Translational genomics in legumes allowed placing in silico 5460 unigenes on the pea functional map and identified candidate genes in Pisum sativum L. G3 Genes Genom. Genet. 1(2), 93-103 (2011). 
25. Gottschalk, W. A Pisum gene preventing transition from the vegetative to the reproductive stage. Pisum Newsletter 11 (1979).

26. Reid, J. \& Murfet, I. Flowering in Pisum: A fifth locus. Veg. Ann. Bot. 53, 369-382 (1984).

27. King, W. \& Murfet, I. Flowering in Pisum: a sixth locus, Dne. Ann. Bot. 56, 835-846 (1985).

28. Weller, J. L. et al. A conserved molecular basis for photoperiod adaptation in two temperate legumes. Proc. Natl. Acad. Sci. 109, 21158-21163 (2012).

29. Weller, J. L. \& Ortega, R. Genetic control of flowering time in legumes. Front. Plant Sci. 6, 207 (2015).

30. Arumingtyas, E. \& Murfet, I. Flowering in Pisum: A further gene controlling response to photoperiod. J. Hered. 85, 12-17 (1994).

31. Prioul, S., Frankewitz, A., Deniot, G., Morin, G. \& Baranger, A. Mapping of quantitative trait loci for partial resistance to Mycosphaerella pinodes in pea (Pisum sativum L.), at the seedling and adult plant stages. Theoret. Appl. Genet. 108, 1322-1334 (2004).

32. Lejeune-Henaut, I. et al. The flowering locus $\mathrm{Hr}$ colocalizes with a major QTL affecting winter frost tolerance in Pisum sativum L. Theor. Appl. Genet. 116, 1105-1116 (2008).

33. Adhikari, K. N., Khan, T. N., Stefanova, K. \& Pritchard, I. Recurrent breeding method enhances the level of blackspot (Didymella pinodes (Berk. \& Blox.) Vestergr.) resistance in field pea (Pisum sativum L.) in southern Australia. Plant Breed. 133, 508-514 (2014).

34. Vega, U. \& Frey, K. Transgressive segregation in inter and intraspecific crosses of barley. Euphytica 29, 585-594 (1980).

35. DeVicente, M. \& Tanksley, S. QTL analysis of transgressive segregation in an interspecific tomato cross. Genetics 134, 585-596 (1993).

36. Rieseberg, L. H., Archer, M. A. \& Wayne, R. K. Transgressive segregation, adaptation and speciation. Heredity 83, 363-372 (1999).

37. Fondevilla, S., Cubero, J. I. \& Rubiales, D. Inheritance of resistance to Mycosphaerella pinodes in two wild accessions of Pisum. In Ascochyta Blights of Grain Legumes (eds İn Tivoli, B. et al.) 53-58 (Springer, New York, 2007).

38. Esen, A. et al. Screening and selection of accessions in the genus Pisum L. for resistance to pulse beetle (Callosobruchus chinensis L.). Euphytica 215, 1-9 (2019).

39. McPhee, K. E., Tullu, A., Kraft, J. M. \& Muehlbauer, F. J. Resistance to Fusarium wilt race 2 in the Pisum core collection. J. Am. Soc. Hortic. Sci. 124, 28-31 (1999).

40. Clement, S., Hardie, D. \& Elberson, L. Variation among accessions of Pisum fulvum for resistance to pea weevil. Crop Sci. 42, 2167-2173 (2002).

41. Clement, S., McPhee, K., Elberson, L. \& Evans, M. Pea weevil, Bruchus pisorum L. (Coleoptera: Bruchidae), resistance in Pisum sativum $\times$ Pisum fulvum interspecific crosses. Plant Breed. 128, 478-485 (2009).

42. Hance, S., Grey, W. \& Weeden, N. Identification of tolerance to Fusarium solani in Pisum sativum ssp. elatius. Pisum Genet. 36, 9-13 (2004).

43. Fondevilla, S., ÅVila, C., Cubero, J. \& Rubiales, D. Response to Mycosphaerella pinodes in a germplasm collection of Pisum spp. Plant Breed. 124, 313-315 (2005).

44. Fondevilla, S. et al. Identification of common genomic regions controlling resistance to Mycosphaerella pinodes, earliness and architectural traits in different pea genetic backgrounds. Euphytica 182, 43-52 (2011).

45. Byrne, O., Hardie, D., Khan, T., Speijers, J. \& Yan, G. Genetic analysis of pod and seed resistance to pea weevil in a Pisum sativum $\times$ P. fulvum interspecific cross. Aust. J. Agric. Res. 59, 854-862 (2008).

46. Barilli, E., Sillero, J., Moral, A. \& Rubiales, D. Characterization of resistance response of pea (Pisum spp.) against rust (Uromyces pisi). Plant Breed. 128, 665-670 (2009).

47. Coyne, C. J. et al. Genetic adjustment to changing climates: Pea. in Crop Adaptation to Climate Change 238-250 (Wiley Online Library, 2011).

48. Aryamanesh, N. et al. Large-scale density-based screening for pea weevil resistance in advanced backcross lines derived from cultivated field pea (Pisum sativum) and Pisum fulvum. Crop Pasture Sci. 63, 612-618 (2012).

49. Aryamanesh, N. et al. Identification of genome regions controlling cotyledon, pod wall/seed coat and pod wall resistance to pea weevil through QTL mapping. Theor. Appl. Genet. 127, 489-497 (2014).

50. Carrillo, E., Rubiales, D., Pérez-de-Luque, A. \& Fondevilla, S. Characterization of mechanisms of resistance against Didymella pinodes in Pisum spp. Eur. J. Plant Pathol. 135, 761-769 (2013).

51. Smýkal, P. et al. Genomic diversity and macroecology of the crop wild relatives of domesticated pea. Sci. Rep. 7, 1-12 (2017).

52. Trněný, O. et al. Molecular evidence for two domestication events in the pea crop. Genes 9, 535 (2018).

53. Byrne, O. M. T. Incorporation of pea weevil resistance from wild pea (Pisum fulvum) into cultivated field pea (Pisum sativum) (University of Western Australia, 2005).

54. Ben Ze'ev, N. \& Zohary, D. Species relationships in the genus Pisum L. Israel J. Bot. (1973).

55. Smýkal, P. et al. Correction: Genetic structure of wild pea (Pisum sativum subsp. elatius) populations in the northern part of the fertile crescent reflects moderate cross-pollination and strong effect of geographic but not environmental distance. PLoS ONE 13, e0196376 (2018).

56. Kosterin, O., Bogdanova, V. \& Galieva, E. Reciprocal compatibility within the genus Pisum L. as studied in F1 hybrids: 2 . Crosses involving P. fulvum Sibth et Smith. Genet. Resour. Crop Evolut. 66, 383-399 (2019).

57. Mendel, G. Versuche uber pflanzen-hybriden. Vorgelegt in den Sitzungen (1865).

58. Bogdanova, V. \& Kosterin, O. Hybridization barrier between Pisum fulvum Sibth. et Smith and P. sativum L. is partly due to nuclear-chloroplast incompatibility. Pisum Genet. 39, 8-9 (2007).

59. Ochatt, S. et al. Overcoming hybridization barriers between pea and some of its wild relatives. Euphytica 137, 353-359 (2004).

60. Jha, A. B., Tar'an, B., Stonehouse, R. \& Warkentin, T. D. Identification of QTLs associated with improved resistance to ascochyta blight in an interspecific pea recombinant inbred line population. Crop Sci. 56, 2926-2939 (2016).

61. Guindon, M. F., Martin, E., Cravero, V. \& Cointry, E. Transgressive segregation, heterosis and heritability for yield-related traits in a segregating population of Pisum sativum L. Exp. Agric. 55, 610-620 (2019).

62. Sarawat, P., Stoddard, F., Marshall, D. \& Ali, S. Heterosis for yield and related characters in pea. Euphytica 80, 39-48 (1994).

63. Srivastava, P. L., Santoshi, U. S. \& Singh, H. G. Combining ability and heterosis in pea. Crop. Impr. 13, 20-23 (1986).

64. Gupta, K. R. \& Dahiya, B. S. Inheritance of pod yield traits in pea. Crop Impr. (1986).

65. Singh, K. N., Sentoshi, U. S. \& Singh, H. G. Genetic analysis of yield components and protein content in pea. The analysis of general and specific combining ability. Indian J. Genet. 47, 115-118 (1987).

66. Koseoglu, K. et al. Transgressive segregations for yield criteria in reciprocal interspecific crosses between Cicer arietinum L. and C. reticulatum Ladiz. Euphytica 213, 116 (2017).

67. Singh, M., Rani, S., Malhotra, N., Katna, G. \& Sarker, A. Transgressive segregations for agronomic improvement using interspecific crosses between C. arietinum L. x C. reticulatum Ladiz and C. arietinum L. x C. echinospermum Davis species. PLoS ONE 13, 203082 (2018).

68. Burstin, J. et al. Microsatellite polymorphism in Pisum sativum. Plant Breed. 120, 311-317 (2001).

69. Nasiri, J., Haghnazari, A. \& Saba, J. Genetic diversity among varieties and wild species accessions of pea (Pisum sativum L.) based on SSR markers. Afr. J. Biotechnol. 8 (2009).

70. Jing, R. et al. The genetic diversity and evolution of field pea (Pisum) studied by high throughput retrotransposon based insertion polymorphism (RBIP) marker analysis. BMC Evol. Biol. 10, 1-20 (2010).

71. Watts, L., Stevenson, E. \& Crampton, M. Inheritance of flowering time in six pea cultivars (Pisum sativum L.). Euphytica 19, 405-410 (1970). 
72. Anbessa, Y., Warkentin, T., Vandenberg, A. \& Ball, R. Inheritance of time to flowering in chickpea in a short-season temperate environment. J. Hered. 97, 55-61 (2006).

73. Tedin, H. \& Tedin, O. Contributions to the genetics of Pisum: III: Internode length, stem thickness and place of the first flower. Hereditas 4, 351-362 (1923).

74. Barber, H. N. Physiological genetics of Pisum II. Heredity 13, 33-60 (1959).

75. Smýkal, P., Coyne, C., Redden, R. \& Maxted, N. Peas. In Genetic and Genomic Resources of Grain Legume Improvement (eds. Singh, M., Uphadyaya, H. D. \& Bisht, I. S.) 41-80 (Elsevier, 2013).

76. Liew, L. C., Hecht, V., Sussmilch, F. C. \& Weller, J. L. The pea photoperiod response gene STERILE NODES is an ortholog of LUX ARRHYTHMO. Plant Physiol. 165, 648-657 (2014).

77. Onyekachi, O. G., Boniface, O. O., Gemlack, N. F. \& Nicholas, N. The effect of climate change on abiotic plant stress: A review. Abiot. Biot. Stress Plants (2019).

78. Schiermeier, Q. Eat less meat: UN climate-change report calls for change to human diet. Nature 572, 291-292 (2019).

79. Food and Agriculture Organization of the United Nations (FAO). The future of food and agriculture: Trends and challenges (2017).

80. Food and Agriculture Organization of the United Nations (FAO). The State of Food Security and Nutrition in the World, Building climate resilience for food security and nutrition (2018).

81. Change, P. C. Global warming of 1.5 C. World Meteorological Organization, Geneva, Switzerland 10 (2018).

82. Compant, S., Van Der Heijden, M. G. \& Sessitsch, A. Climate change effects on beneficial plant-microorganism interactions. FEMS Microbiol. Ecol. 73, 197-214 (2010).

83. Toker, C., Canci, H. \& Yildirim, T. Evaluation of perennial wild Cicer species for drought resistance. Genet. Resour. Crop Evol. 54, 1781-1786 (2007).

84. Toker, C., \& Mutlu, N. Breeding for abiotic stresses. İn Biology and Breeding of Food Legumes (ed: Pratap, A., \& Kumar, J.) 241-261 (2011).

85. Kooyers, N. J. The evolution of drought escape and avoidance in natural herbaceous populations. Plant Sci. 234, 155-162 (2015).

86. World Health Organization. Modes of transmission of virus causing COVID-19: implications for IPC precaution recommendations. (2020). (No. WHO/2019-nCoV/Sci_Brief/Transmission_modes/2020.1).

87. Siddique, K.M.H. http://www.news.uwa.edu.au/2020042012008/international/ensuring-global-food-security-during-covid-19 (Accessing date: 06.05.2020). (2020).

88. Food and Agriculture Organization of the United Nations (FAO). Hunger and food insecurity (2019).

89. Food and Agriculture Organization of the United Nations (FAO). COVID-19 pandemic-impact on food and agriculture (2020).

90. Singh, A., Singh, S. \& Babu, J. D. P. Heritability, character association and path analysis studies in early segregating population of field pea (Pisum sativum L. var. arvense). Int. J. Plant Breed. Genet. 5, 86-92 (2011).

91. Esposito, M. A. et al. Principal component analysis based on morphological characters in pea (Pisum sativum L.). Int. J. Plant Breed. 1, 135-137 (2007).

92. Singh, S. \& Srivastava, S. Comparison of direct and indirect effects of yield traits on yield in tall and dwarf genotypes of pea (Pisum sativum L.). Indian J. Plant Genet. Resour. 14, 201-202 (2001).

93. Tiwari, S., Singh, H., Kumar, R., Nigam, H. \& Singh, A. A postmortem of selection parameters in pea (Pisum sativum L.). Crop Res. 2, 237-242 (2001).

94. Rick, C. M. \& Smith, P. G. Novel variation in tomato species hybrids. Am. Nat. 87, 359-373 (1953).

95. Grant, V. Genetics of Flowering Plants (Columbia University Press, 1978).

96. Poehlman, J. M. \& Sleper, D. A. Breeding Field Crops (Iowa State University Press, 1995).

97. Steel, R. G. D. \& Torrie, J. H. Principles and Procedures of STATISTICS (McGraw-Hill, 1980).

\section{Acknowledgements}

This study was a part of PhD thesis of HS. Authors are thankful to the funding council that supported this work, agronomist Mr. Veysel Dogdu for reciprocal crossing interspecific crosses between P. sativum and P. fulvum. Authors are also grateful to the reviewers for their thoughtful input on earlier versions of this manuscript.

\section{Author contributions}

H.S. and C.T. designed the study. H.S. conducted study. This article is a part of unpublished PhD this by H.S. D.S. and T.E. assisted H.S. H.S. wrote the main manuscript text and C.T. revised the manuscript before submission. All authors contributed to the article and approved the submitted version.

\section{Funding}

The present study was financially supported by Akdeniz University Scientific Research Project Coordination Unit (FDK-2020-5257).

\section{Competing interests}

The authors declare no competing interests.

\section{Additional information}

Correspondence and requests for materials should be addressed to H.S.

Reprints and permissions information is available at www.nature.com/reprints.

Publisher's note Springer Nature remains neutral with regard to jurisdictional claims in published maps and institutional affiliations. 
(c) (i) Open Access This article is licensed under a Creative Commons Attribution 4.0 International cc) License, which permits use, sharing, adaptation, distribution and reproduction in any medium or format, as long as you give appropriate credit to the original author(s) and the source, provide a link to the Creative Commons licence, and indicate if changes were made. The images or other third party material in this article are included in the article's Creative Commons licence, unless indicated otherwise in a credit line to the material. If material is not included in the article's Creative Commons licence and your intended use is not permitted by statutory regulation or exceeds the permitted use, you will need to obtain permission directly from the copyright holder. To view a copy of this licence, visit http://creativecommons.org/licenses/by/4.0/.

(C) The Author(s) 2021 